\title{
Beyond the One-Drop Rule: Views of Obama's Race and Voting Intention in 2008
}

\author{
Simon Cheng, David L. Weakliem
}

University of Connecticut

\begin{abstract}
We use data from a national survey of likely voters conducted before the 2008 election to study the association between Obama's perceived racial identity and voters' choices. Voters who saw Obama as biracial were substantially more likely to vote for him, suggesting that many Americans regard a biracial identity more favorably than a black identity. The relationship was stronger among Democrats than among Republicans. The potential implications of our findings for the future of race in American politics are discussed.
\end{abstract}

Keywords: Obama; biracial perception; 2008 presidential election; black president

Editor(s): Jesper Sørensen, Sarah Soule; Received: September 17, 2013; Accepted: November 5, 2013; Published: March 17, 2014

Citation: Cheng, Simon, and David L. Weakliem. 2014. “Beyond the One-Drop Rule: Views of Obama's Race and Voting Intention in 2008." Sociological Science 1: 70-80. DOI: 10.15195/v1.a6

Copyright: (C) 2014 Cheng and Weakliem. This open-access article has been published and distributed under a Creative Commons Attribution License, which allows unrestricted use, distribution and reproduction, in any form, as long as the original author and source have been credited.

THE election of Barack Obama in 2008 was 1 undoubtedly a historic event, but its meaning is open to different interpretations. Although Obama is normally described as the first black president, he could also be called the first multiracial president. However, although there have been many studies of the role of race in the election, few have examined the effect of Obama's biracial background. This oversight is striking given the rapid growth of multiracial populations and the emergence of a multiracial identity as an alternative to the traditional "one-drop rule" (Harris and Sim 2002; Lee and Bean 2010). In this paper, we begin to fill this gap by examining the association between perceptions of Obama's race and voting choice in the 2008 election.

Obama's biracial ancestry was not just a biographical detail: he often referred to it in his writings and public statements. In the early stages of the campaign, there was a good deal of speculation about how voters might react. Some observers questioned whether the black community would fully accept Obama (Bacon 2007; Crouch 2006). Others suggested that his biracial parentage would make him more acceptable to white voters (Coates 2007). However, as time went on, media commentary shifted towards treating Obama as unambiguously black.

The question considered in this paper is of particular interest given contemporary demographic trends. The number of people who have parents of different races has been increasing for decades (Lofquist et al. 2012). Moreover, people with mixed ancestry are increasingly likely to self-identify as multiracial. Some observers argue that the growth of multiracial identities will transform race relations, either by weakening racial boundaries or by producing a more flexible view of "race" (Patterson 1997). Others emphasize the strength of racial boundaries and suggest that a black-nonblack divide is emerging as a primary organizing principle (Lee and Bean 2010). Our examination of the 2008 election contributes to this debate by asking whether perception of a biracial identity is relevant to an important behavior - voting choices.

\section{Background}

Tajfel (1981) proposes that people distinguish between in- and out-group members (or "we" and "them"). Voters can be expected to react more favorably to candidates who are part of their own group (Block 2011; Caruso, Mead, and Balcetis 2009). Similarly, they may be influenced by a biracial background, for example by regarding it as "somewhat we" (Cheng and Lively 2009). On the other hand, it is possible that voters who intended to support Obama assigned him to the 
category that they regarded more favorably, while those who intended to vote against him consigned him to the one that they regarded less favorably. That is, perceptions of Obama's race may have been rationalizations for voting decisions.

Our analysis treats support for Obama as the dependent variable and views of his racial identity as an independent variable. Our specification should not be taken as a claim about causal order, which cannot be definitively established with cross-sectional data. However, the sign and significance of any association will be the same regardless of whether biracial perception is treated as an independent or dependent variable. Theoretically, an association is of interest regardless of the causal order, because in either case it means that one identity is valued over another.

Existing theories suggest three possibilities:

1. Views of Obama's race had no effect: Obama might have established a personal image in which race was largely irrelevant, as Kinder and McConnaughy (2006) argued that Colin Powell did in the 1990s. It is also possible that biracial identity involves both positive and negative connotations that more or less balance out, leaving no net effect.

2. Support was higher among voters who saw Obama as biracial: Popular media have portrayed people with multiracial backgrounds very favorably in recent years, implying that they can help to overcome racial divisions and bridge cultural differences (Lanning and Maruyama 2010; Morning 2005). This point suggests that Obama's biracial status might have been a positive attraction for some voters ${ }^{1}$ Another possibility is that racial prejudice could produce an association: voters who could not accept an unambiguously black candidate could rationalize support for Obama if they saw him as multiracial.

\footnotetext{
${ }^{1}$ Lighter skin tone may have helped Obama in the election. However, in the prevailing American view of race, "light-skinned black" and multiracial are distinct identities (Herring, Keith, and Horton 2004). Prior to Obama, several prominent African American political figures had relatively light skin, but were invariably spoken of as black.
}

3. Support was lower among voters who saw Obama as biracial: A biracial identity can be unsettling to people who are used to a clear distinction between races (Moran 2001:119-21). Both before and after the election, a major theme among Obama's critics was that some people could not be sure about "the real Obama": that he was hiding something about his past or his true beliefs (Nossiter 2008; Smith and King 2009). Even when race was not explicitly mentioned, such criticisms may have triggered latent fears about multiracial people. That is, seeing Obama as multiracial might have been associated with seeing him as untrustworthy or unreliable.

Whatever its prevailing direction, any relationship could be contingent on other voter characteristics. One possibility is that being seen as biracial would hurt Obama among blacks but help him among whites Block (2011), however, notes that blacks have more "practice" than whites in voting for candidates who are not of their own race. His point suggests that being seen as biracial would help among whites but make little or no difference among blacks. That is, whites would be more willing to accept a partly white candidate than a black one, while blacks would give Obama uniformly high support in the 2008 election regardless of their perception of his race. The relationship might also differ by party. Some Democratic voters might have agreed with Obama's political views but felt reluctant to vote for a black candidate. Such voters might be more likely to support Obama if they saw him as biracial, while Republicans would be unlikely to support him in any case (Caruso, Mead, and Balcetis 2009).

\section{Methods}

Although Obama's biracial background was widely discussed in the media, there is little data on how the general public saw the question. In this study, we employ data from one of the few surveys that asked about the issue. The survey of 1,133 likely voters was sponsored by Time magazine and conducted in late September 2008. By that time, the campaign was well advanced, and most voters 
had a definite preference between the presidential candidates.

Views of Obama's racial identity are measured by responses to the statement: "Barack Obama isn't white or black; he's a little of both." Respondents were offered four possible responses to the question of how well this statement describes Obama: 42 percent chose "very well," 22 percent "some," 5 percent "not much," and 17 percent "not at all," while 13 percent were not sure or had no opinion. For convenience, we will refer to responses to this statement as "biracial perception."

A drawback of the measure is that respondents could treat it as a matter of factual knowledge about Obama's ancestry. For our purposes, the ideal measure would ask about the implications of the fact for racial identity: for example, whether a person with one black and one white parent should be regarded as black, white, some of both, or if it would depend on the circumstances. Those who said that it depended on the circumstances could be asked to elaborate.

We believe that most respondents interpreted the item in terms of racial identity, because it occurred in a group of items involving judgment rather than factual knowledge. However, it is important to ask how estimates of the relationship could be affected by "literal" interpretations. If there is no association between literal interpretations and the probability of supporting Obama, they can be regarded as measurement error in the independent variable, and the estimated association with voting choices will be biased towards zero. If there is an association - that is, if those who take a literal interpretation have a higher or lower chance of supporting Obama than those who do not - the situation is more complex. We will discuss this issue further in the results section.

Another potential concern over the biracial perception question is that the wording may be biased toward agreement. We tested this possibility by comparing analyses coding biracial perceptions as "very well" versus the other three categories, and as "very well" or "some" versus "not much," and "not at all." The coefficients from the more restrictive coding are both larger and more significant than the coefficients from the less restrictive coding. This suggests that potential bias toward agreement in the biracial perception question would lead to an underestimate of the association, because acquiescence responses tend to attenuate and obscure true effects 2

Respondents were asked if they would vote for the Democratic ticket of Obama and Biden or the Republican ticket of McCain and Palin "if the Presidential election were held today." Those who were undecided were asked if they leaned towards one side. Our analysis combines "leaners" with those who expressed a clear preference. About 5 percent were undecided and had no preference, while 2 percent said that they would vote for a minor-party candidate. These cases were excluded from the analysis.

Research on American elections routinely includes race, religion, and class as control variables. We represent ethnicity by three categories: non-Hispanic whites, blacks, and all other ethnicities. Religious denomination is coded as Catholic, evangelical Protestants, and all others. We also include a measure of whether the respondent regularly attends religious services. Socioeconomic status is measured by education, family income, and employment status. Additional controls include gender, age, marital status, region, party identification, and self-rated political ideology. The Appendix reports details of these variables.

\section{Results}

Before beginning the main analysis, it is important to ask whether views of Obama's race represented distinct attitudes. The item was part of a series of statements about Obama's qualities, most of which can be characterized as unambiguously positive or negative. It is possible that respondents reacted to all statements, including the one on racial identity, in terms of general approval or disapproval. Table 1 shows that correlations of variables involving biracial perception are considerably lower than those among all other variables. A factor analysis found a primary factor that can plausibly be interpreted as general

\footnotetext{
2 Two recent surveys in 2009 and 2011 asked whether respondents "mostly think of (Barack) Obama as ... a black person or mostly as a person of mixed race?" About half said that they thought of him as a person of mixed race, 25 percent as black, and 15 percent volunteered an intermediate response. This is similar to the distribution of responses to the Time magazine question in 2008, suggesting that expressed opinions on the topic are not particularly sensitive to question wording.
} 
Table 1: Pairwise Correlation Coefficients Between Biracial Perception and Other Measures of Barack Obama and His Presidential Campaign

How well does each of the following statements describe Barack Obama and his campaign for the presidency? ... very well, some, not much, or not at all?

(1)

(2)

(3)

(4)

(5)

(1) Biracial perception: Barack Obama 1.00 isn't white or black; he's a little of both.

(2) Obama is pretty much just another politician.

(3) Obama's election would help to heal American's racial history and divisions.

(4) Obama gives a great speech, but doesn't have many other qualifications for president.

(5) The real Barack Obama holds extreme positions which won't be revealed until after he's elected, no matter what he says now.

(6) Barack Obama's election to the presidency would help restore a sense of hope and inspiration to America.

(7) Barack Obama brings together people of different races and backgrounds.

(8) Barack Obama's policies would favor minorities over white people.

$0.09 \quad 1.00$

$\begin{array}{lll}0.20 & 0.38 & 1.00\end{array}$

$\begin{array}{llll}0.06 & 0.60 & 0.44 & 1.00\end{array}$

$\begin{array}{lllll}0.01 & 0.51 & 0.34 & 0.56 & 1.00\end{array}$

$\begin{array}{llllll}0.19 & 0.54 & 0.67 & 0.62 & 0.48 & 1.00\end{array}$

$\begin{array}{lllllll}0.21 & 0.38 & 0.56 & 0.42 & 0.38 & 0.65 & 1.00\end{array}$

$\begin{array}{llllllll}0.00 & -0.43 & -0.30 & -0.50 & -0.49 & -0.45 & -0.39 & 1.00\end{array}$

Note: Data are from Time Magazine Poll - 2008-4556, September 26-29, 2008.

favorability: the question on racial identity had a loading of only 0.21 , while all other items had much higher loadings. On a second factor, the question about racial identity had a loading of 0.78 , while the loadings of all other items were less than 0.3. These patterns indicate that views of Obama's racial identity were a distinct attitude, not merely a reflection of general positive or negative feelings.

Table 2 shows support for Obama by biracial perception. To facilitate presentation, we combined respondents into two groups: those who said that the statement described him "very well" or "some" and those who said "not much" or "not at all." Approximately 59 percent of those who agreed that Obama was "a little of both," but only 44 percent of those who disagreed, intended to vote for him. The same pattern appears in almost all subgroups - the most notable exception is among strong Republicans. Table 2 also shows the percentage of each demographic group that saw Obama as biracial. Most group differences are small and do not reach statistical significance, but liberals, Democrats, and blacks were more likely to view Obama as biracial.

Table 3 reports estimates from logistic regressions using sampling weights provided in the survey (the unweighted estimates are very similar). Preliminary examination suggested that support for Obama was about the same in the "very well" and "some" categories, and in "not much" and "not at all." Consequently, we collapsed the original scale into a binary variable representing general agreement or disagreement ${ }^{3}$ An indicator variable was used for respondents who answered "don't know" to the question on biracial perception. Analyses using multiple imputations for these cases showed similar results.

Model 1 includes only the biracial perception variables. The estimate implies that viewing

\footnotetext{
3 Analyses coding biracial perceptions as an ordinal variable produced very similar results.
} 
Table 2: Support for Obama in the Presidential Election and Perception of Obama as Biracial by Selected Sociodemographic Characteristics

\begin{tabular}{|c|c|c|c|c|c|c|}
\hline \multirow[b]{3}{*}{ Group Categories } & \multicolumn{4}{|c|}{ \% Supporting Obama } & \multirow{3}{*}{$\begin{array}{c}\text { \% Perceiving } \\
\text { Obama as } \\
\text { Biracial }\end{array}$} & \multirow{3}{*}{$\begin{array}{l}\text { Group } \\
\text { Size }\end{array}$} \\
\hline & \multirow[b]{2}{*}{ Total } & \multicolumn{3}{|c|}{$\begin{array}{l}\text { Perceive Obama } \\
\text { as Biracial }\end{array}$} & & \\
\hline & & Yes & No & Diff. & & \\
\hline Overall sample & 53.8 & 59.2 & 43.7 & $15.5^{\dagger}$ & 65.2 & 1,053 \\
\hline \multicolumn{7}{|l|}{ Age } \\
\hline $18-34$ & 53.7 & 61.0 & 37.7 & $23.3^{\dagger}$ & 68.6 & 156 \\
\hline $35-54$ & 53.3 & 58.7 & 44.8 & $13.9 *$ & 61.6 & 380 \\
\hline$\geq 55$ & 54.5 & 58.5 & 46.4 & $12.1 *$ & 67.1 & 517 \\
\hline \multicolumn{7}{|l|}{ Gender } \\
\hline Female & 59.2 & 64.6 & 47.8 & $16.8^{\dagger}$ & 67.7 & 545 \\
\hline Male & 48.1 & 53.0 & 39.9 & $13.1^{\dagger}$ & 62.6 & 508 \\
\hline \multicolumn{7}{|l|}{ Race/ethnicity ${ }^{\mathrm{a}}$} \\
\hline White & 45.5 & 51.0 & 35.4 & $15.6^{\dagger}$ & 64.7 & 778 \\
\hline Black & 97.9 & 99.1 & 94.9 & 4.2 & 72.3 & 197 \\
\hline Other minorities & 62.8 & 67.2 & 55.1 & 12.2 & 63.8 & 70 \\
\hline \multicolumn{7}{|l|}{ Education } \\
\hline High school or less & 52.1 & 59.5 & 36.2 & $23.4^{\dagger}$ & 68.3 & 242 \\
\hline College or more & 54.3 & 59.1 & 45.6 & $13.5^{\dagger}$ & 64.4 & 811 \\
\hline \multicolumn{7}{|l|}{ Religion } \\
\hline Catholic & 49.9 & 54.1 & 42.1 & 12.0 & 65.4 & 244 \\
\hline Evangelical & 34.8 & 42.0 & 22.7 & $19.3^{\dagger}$ & 62.8 & 232 \\
\hline \multicolumn{7}{|l|}{ Protestant } \\
\hline Other & 62.5 & 67.5 & 52.8 & $14.8^{\dagger}$ & 66.0 & 577 \\
\hline \multicolumn{7}{|c|}{ Regular church attendance } \\
\hline Yes & 45.6 & 50.0 & 38.5 & $11.5 *$ & 61.9 & 585 \\
\hline No & 63.4 & 68.8 & 51.1 & $17.7^{\dagger}$ & 69.1 & 468 \\
\hline \multicolumn{7}{|l|}{ Region } \\
\hline Northeast & 53.2 & 54.4 & 51.1 & 3.3 & 63.8 & 197 \\
\hline Midwest & 62.3 & 67.0 & 52.4 & $14.6 *$ & 67.9 & 244 \\
\hline South & 46.9 & 54.6 & 32.2 & $22.4^{\dagger}$ & 65.6 & 393 \\
\hline West & 56.3 & 62.0 & 46.5 & $15.5 *$ & 63.0 & 219 \\
\hline \multicolumn{7}{|l|}{ Party affiliation } \\
\hline Strong Republican & 9.0 & 8.1 & 10.2 & -2.1 & 58.4 & 300 \\
\hline Republican & 11.7 & 16.5 & 3.8 & $12.7 *$ & 62.3 & 124 \\
\hline Independent & 48.3 & 49.4 & 45.9 & 3.5 & 68.4 & 66 \\
\hline Democrat & 88.8 & 93.9 & 70.2 & $23.7^{\dagger}$ & 78.5 & 138 \\
\hline Strong Democrat & 90.8 & 94.3 & 83.8 & $10.5 *$ & 66.2 & 425 \\
\hline \multicolumn{7}{|l|}{ Political attitudes } \\
\hline Very conservative & 22.6 & 26.2 & 16.2 & 10.0 & 63.4 & 167 \\
\hline Conservative & 29.5 & 37.7 & 17.5 & $20.3^{\dagger}$ & 59.6 & 292 \\
\hline Moderate & 59.7 & 60.9 & 57.4 & 3.5 & 65.4 & 322 \\
\hline Liberal & 87.8 & 90.7 & 80.6 & 10.1 & 70.6 & 180 \\
\hline Very liberal & 92.6 & 94.6 & 86.8 & 7.8 & 74.1 & 92 \\
\hline
\end{tabular}

Note: Data are from Time Magazine Poll - 2008-4556, September 26-29, 2008. Analyses are weighted and restricted to Obama or McCain supporters. ${ }^{a}$ Races missing subjects are not reported. ${ }^{*} p<.05 .{ }^{\dagger} p<.01$ (2-tailed.) 
Table 3: Weighted Logistic Regression Analysis of Biracial Effects on Support for Barak Obama over John McCain

\begin{tabular}{|c|c|c|c|c|}
\hline & (1) & $(2)$ & (3) & (4) \\
\hline Biracial perception & $\begin{array}{r}0.62^{\dagger} \\
(0.17)\end{array}$ & $\begin{array}{r}0.65^{\dagger} \\
(0.21)\end{array}$ & $\begin{array}{c}0.62 * \\
(0.31)\end{array}$ & $\begin{array}{r}-0.63 \\
(0.58)\end{array}$ \\
\hline Age in years & & $\begin{array}{c}0.01 \\
(0.01)\end{array}$ & $\begin{array}{c}0.01 \\
(0.01)\end{array}$ & $\begin{array}{c}0.01 \\
(0.01)\end{array}$ \\
\hline Female & & $\begin{array}{r}0.54^{\dagger} \\
(0.17)\end{array}$ & $\begin{array}{l}0.28 \\
(0.24)\end{array}$ & $\begin{array}{c}0.29 \\
(0.24)\end{array}$ \\
\hline Black & & $\begin{array}{l}4.83^{\dagger} \\
(0.5)\end{array}$ & $\begin{array}{r}3.49^{\dagger} \\
(0.54)\end{array}$ & $\begin{array}{r}3.54^{\dagger} \\
(0.55)\end{array}$ \\
\hline Nonblack racial/ethnic minorities & & $\begin{array}{r}1.00^{\dagger} \\
(0.31)\end{array}$ & $\begin{array}{c}0.82 \\
(0.45)\end{array}$ & $\begin{array}{c}0.88 \\
(0.46)\end{array}$ \\
\hline Education in years & & $\begin{array}{c}0.11^{\dagger} \\
(0.04)\end{array}$ & $\begin{array}{c}0.07 \\
(0.06)\end{array}$ & $\begin{array}{c}0.07 \\
(0.06)\end{array}$ \\
\hline Family income & & $\begin{array}{c}0.00 \\
(0.00)\end{array}$ & $\begin{array}{c}0.00 \\
(0.00)\end{array}$ & $\begin{array}{c}0.00 \\
(0.00)\end{array}$ \\
\hline Part-time employed & & $\begin{array}{c}0.51 \\
(0.27)\end{array}$ & $\begin{array}{l}1.00 \\
(0.53)\end{array}$ & $\begin{array}{l}1.00 \\
(0.55)\end{array}$ \\
\hline Other employment status & & $\begin{array}{c}0.21 \\
(0.19)\end{array}$ & $\begin{array}{c}0.52 \\
(0.28)\end{array}$ & $\begin{array}{c}0.45 \\
(0.29)\end{array}$ \\
\hline Marital status $($ married $=1)$ & & $\begin{array}{c}-0.26 \\
(0.18)\end{array}$ & $\begin{array}{c}0.46 \\
(0.28)\end{array}$ & $\begin{array}{c}0.45 \\
(0.28)\end{array}$ \\
\hline Catholic & & $\begin{array}{c}-0.16 \\
(0.20)\end{array}$ & $\begin{array}{c}-0.22 \\
(0.29)\end{array}$ & $\begin{array}{r}-0.22 \\
(0.30)\end{array}$ \\
\hline Evangelical Protestant & & $\begin{array}{r}-0.99^{\dagger} \\
(0.23)\end{array}$ & $\begin{array}{c}-0.33 \\
(0.37)\end{array}$ & $\begin{array}{r}-0.31 \\
(0.38)\end{array}$ \\
\hline Regular church attendance & & $\begin{array}{r}-0.94^{\dagger} \\
(0.17)\end{array}$ & $\begin{array}{c}-0.54 * \\
(0.26)\end{array}$ & $\begin{array}{r}-0.56 * \\
(0.26)\end{array}$ \\
\hline Midwest & & $\begin{array}{r}0.64^{\dagger} \\
(0.24)\end{array}$ & $\begin{array}{c}0.57 \\
(0.38)\end{array}$ & $\begin{array}{c}0.58 \\
(0.39)\end{array}$ \\
\hline South & & $\begin{array}{c}-0.33 \\
(0.24)\end{array}$ & $\begin{array}{c}0.00 \\
(0.33)\end{array}$ & $\begin{array}{c}-0.01 \\
(0.34)\end{array}$ \\
\hline West & & $\begin{array}{c}0.27 \\
(0.26)\end{array}$ & $\begin{array}{r}0.34 \\
-0.38\end{array}$ & $\begin{array}{c}0.35 \\
(0.38)\end{array}$ \\
\hline Party affiliation ( $1=$ strong Republican $)$ & & & $\begin{array}{r}1.10^{\dagger} \\
(0.09)\end{array}$ & $\begin{array}{r}0.86^{\dagger} \\
(0.13)\end{array}$ \\
\hline Political attitudes $(1=$ very conservative $)$ & & & $\begin{array}{c}0.57^{\dagger} \\
(0.14)\end{array}$ & $\begin{array}{r}0.57^{\dagger} \\
(0.15)\end{array}$ \\
\hline Biracial Perception $\times$ Party Affiliation & & & & $\begin{array}{r}0.40 * \\
(0.17)\end{array}$ \\
\hline Undecided/don`t know in biracial perception & $\begin{array}{c}-0.03 \\
(0.24)\end{array}$ & $\begin{array}{c}0.20 \\
(0.29)\end{array}$ & $\begin{array}{c}-0.57 \\
(0.49)\end{array}$ & $\begin{array}{c}-0.38 \\
(0.42)\end{array}$ \\
\hline Constant & $\begin{array}{c}-0.24 \\
(0.14)\end{array}$ & $\begin{array}{r}-2.26^{\dagger} \\
(0.63)\end{array}$ & $\begin{array}{r}-7.78^{\dagger} \\
(1.15)\end{array}$ & $\begin{array}{r}-6.98^{\dagger} \\
(1.15)\end{array}$ \\
\hline Pseudo $R^{2}$ & 0.03 & 0.48 & 0.73 & 0.74 \\
\hline $\mathrm{BIC}$ & $1,451.28$ & $1,254.70$ & 764.49 & 763.76 \\
\hline $\mathrm{N}$ & 1,053 & 1,053 & 1,053 & 1,053 \\
\hline
\end{tabular}

Note: Data are from Time Magazine Poll - 2008-4556, September 26-29, 2008. Analyses are restricted to Obama and McCain supporters; standard errors in. ${ }^{*} p<.05 .{ }^{\dagger} p<.01$ (2-tailed.) 
Obama as biracial was associated with an 86 percent increase in the odds of intending to vote for him. In Model 2, which controls for a variety of demographic characteristics, the estimated effect of biracial perception is slightly larger.

Model 3 includes controls for self-rated ideology and party preference. As expected, liberalism and Democratic Party identification are associated with support for Obama. However, the estimated effect of biracial perception is only slightly smaller than those in Models 1 and 2, and remains statistically significant. Model 3 may go too far in controlling for other influences, since stated party preference may be influenced by intended vote in the upcoming election. Thus, the best estimate of the effects of biracial perceptions probably falls in between those in Models 2 and 3.4

The association between views of Obama's race and voting choices was not just statistically significant, but of substantial magnitude. Obama received almost 60 percent support among voters who saw him as biracial, but well under half among voters who did not, and very little of this difference can be accounted for by demographic or ideological factors.

As discussed in the previous section, some respondents may have responded to the biracial perception question as a factual statement about his ancestry. We tried several numerical examples to test how this literal interpretation may affect our estimated association. The results suggest that estimates of the association would be biased upwards only if the "literalists" had a very strong tendency to support Obama. Because there is no obvious reason to expect that people who took a literal interpretation had a higher probability of voting for Obama, if our estimates are biased, they are likely to be too small rather than too large.

\section{Interactions}

We tested for the possibility of interactions between biracial perception and other independent variables. Only the interaction with party preference was statistically significant (for similar find-

\footnotetext{
4 Inclusion of racial discrimination and views toward blacks did not change the effects of biracial perceptions and resulted in worse model fit statistics.
}

ings, see Block 2011) 5 Results of this analysis are shown as Model 4. The implied effect of biracial perception is $(-0.63+0.40 x)$, where $x$ is party affiliation. The resulting effects of biracial perception range from -0.23 among strong Republicans to 1.37 among strong Democrats. Given the sample size, it is not possible to determine the exact form of the interaction - specifications dividing the party classifications into two groups fit about as well as the one used in Model $4 \sqrt[6]{6}$ However, the conclusion that biracial perception had a more favorable effect among Democrats than among Republicans was robust across different specifications.

Election outcomes depend on vote counts, not on odds ratios, so additional analysis is needed to determine practical implications of the logistic regression estimates. Figure 1 shows the predicted probabilities of support for Obama by biracial perception and party preference implied by Model 4 . The figure shows that biracial perception made little difference for voters who identified as Republicans, but was associated with substantially higher support among independents and Democrats.

Figure 2 includes three independent variablesrace, ideology, and religion - that are statistically significant but have no interaction effects with biracial perception. The top left panel shows the probabilities of supporting Obama among conservative whites who regularly attend church services. Among Republicans, the implied effects are negligible. The difference in probability rises to 0.10 for independents, 0.24 for weak Democrats, and 0.28 for strong Democrats. The remaining three left panels of Figure 2 plot the probabilities for other groups of whites defined by ideology and church attendance. The same general pattern is visible, but differences in probability are smaller because of the high rate of support for Obama among liberals. In the right panels of Figure 2 , we see that the predicted differences due to biracial perception are small among black voters, because support was uniformly high. In terms of the number of votes, biracial perception made

5 The estimated effect of biracial perception was stronger among blacks, but given the high level of black support for Obama, the standard error of the estimate was large and the estimate was not significantly different from zero.

${ }^{6} \mathrm{We}$ found no evidence that the effects of biracial perception were stronger among independents and weak partisan. 


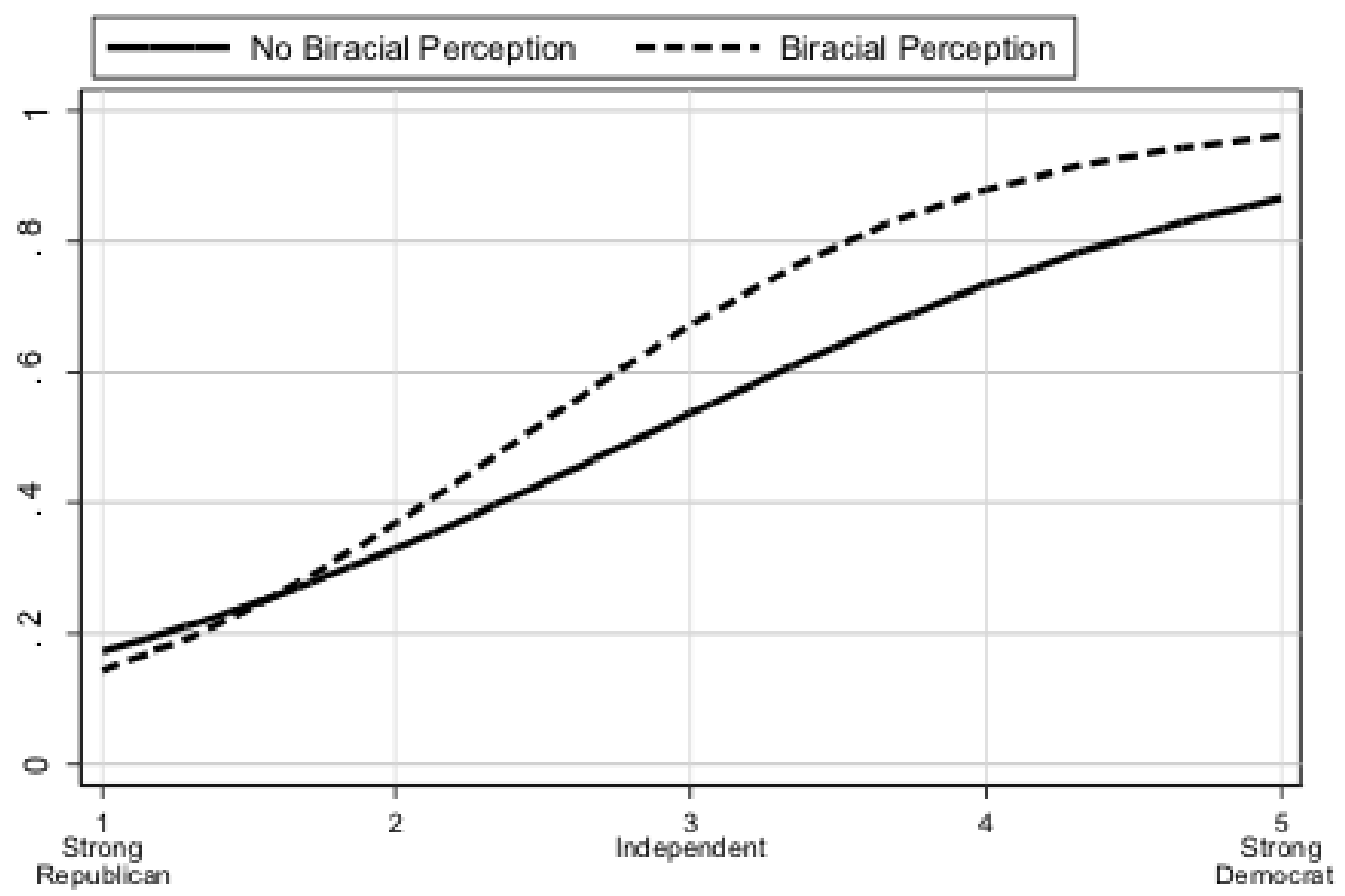

Figure 1: Probability of Support for Barak Obama by Biracial Perception and Party Affiliation. Time Magazine Poll - 2008-4556, September 26-29, 2008. Probabilities are calculated based on Model 4 in Table 3 . All other variables are held at their means.

more difference among whites and conservatives, because these groups were initially more evenly divided.

Turning to the determinants of biracial perception, the traditional dominance of the "onedrop" rule suggests that biracial perception would be more common among younger and more educated respondents, who would be more open to new ideas. However, models including various combinations of the variables in Table 2 had little predictive power, and no significant differences by age, educational level, race, or region were found 7 The only clear finding was that conservatives were less likely to see Obama as biracial. Although it is difficult to interpret a negative finding, the absence of clear group differences is noteworthy. One possible explanation is that the one-drop rule, despite its prominent place in law and policy, never penetrated deeply into public

\footnotetext{
7 The surveys in 2009 and 2011 showed no clear patterns of group difference in perceptions of Obama's racial identity.
}

consciousness. Instead, views of Obama as black or biracial depend mostly on voters' personal experiences and inclinations without connecting to group membership or ideological position. That is, people who regarded Obama as biracial may not have seen themselves as going against tradition. Unfortunately, there is very little survey evidence on multiracial perceptions, but this is an important issue for future research.

\section{Discussion}

We find that a majority of voters viewed Obama as biracial, and this perception was substantially associated with the probability of voting for him in the 2008 election. Regardless of whether support for Obama influenced perceptions of his racial identity or perceptions of his racial identity influenced support, the association suggests that a multiracial identity is valued over a black one. 

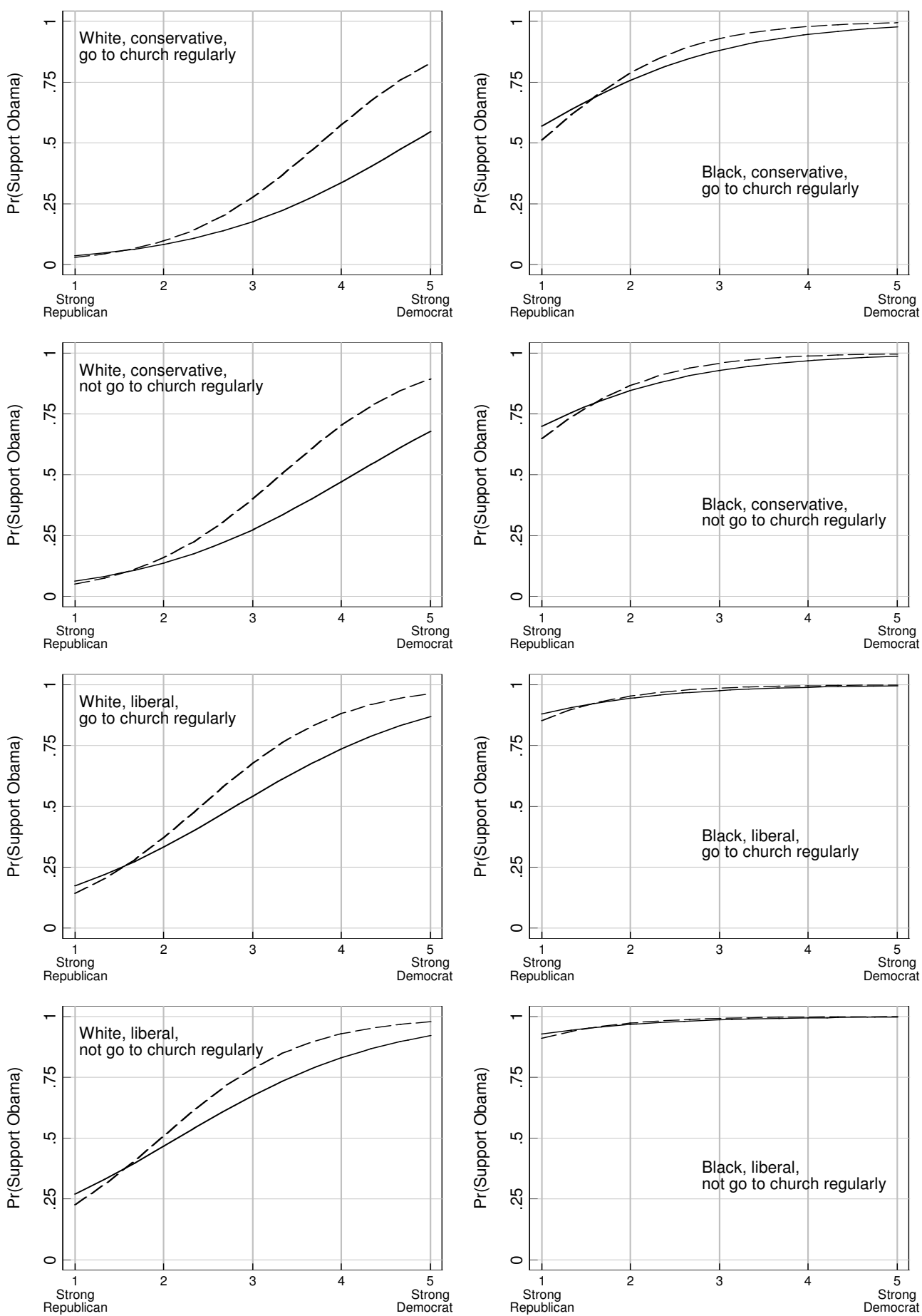

Figure 2: Effects of Biracial Perception on Support for Obama by Party Affiliations. Time Magazine Poll - 2008-4556, September 26-29, 2008. Probabilities are based on Model 4 in Table 2. All other variables are held at means. Dashed line: Biracial perception; Solid line: No biracial perception. 
Both causal orders imply that a candidate's multiracial or black background puts limits on the extent to which undecided voters may be willing to support the candidate. There has been a great deal of debate about the extent and nature of the change in racial attitudes since the 1960s. By electing a non-white president, Americans have given evidence of a real decline in prejudice. At the same time, the association between views of Obama's race and electoral choices provides evidence that race is still important to voters, contrary to some of the more optimistic claims after his election. The generally positive effect of biracial perception may suggest that multiracial identity is now a legitimate racial category, but also shows that black and "less-black" individuals are treated differently.

Obama's victory is likely to encourage more non-white politicians to compete in national elections. Our findings suggest several possibilities about how they will fare. One possibility is that Obama's victory could facilitate a general decline of racial barriers in electoral politics, paralleling the effect of John F. Kennedy's election for religious differences. The strong performance of a black candidate, Herman Cain, in the 2012 Republican primaries may be a sign of such a change. Another possibility, however, is that multiracial candidates could continue to be advantaged relative to black candidates. Finally, it is also possible that Barack Obama was simply an exceptional candidate at an unusual time. The 2008 election was held under the shadow of economic crisis and an unpopular war, and these circumstances may have provided an opening that is unlikely to be replicated. Regardless, this study shows that American voters reacted more positively to a biracial than to a black identity. It remains to be seen whether this difference is a sign of progress, continued prejudice, or a transformation of the way that Americans look at race.

\section{References}

Bacon, Jr., Perry 2007. "Can Obama Count on the Black Vote?" Time, January 23.

Block, Jr., Ray. 2011. "Backing Barack Because He's Black: Racially Motivated Voting in the 2008 Election." Social Science Quarterly
92:423-446. http://dx.doi.org/10.1111/j 1540-6237.2011.00776.x

Caruso, Eugene M., Nicole L. Mead, and Emily Balcetis. 2009. "Political Partisanship Influences Perception of Biracial Candidates' Skin Tone." Proceedings of the National Academy of Sciences 106:20168-20173. http: //dx.doi.org/10.1073/pnas.0905362106

Cheng, Simon and Kathryn J. Lively. 2009. "Multiracial Self-Identification and Adolescent Outcomes: A Social Psychological Approach to the Marginal Man Theory." Social Forces 88:61-98. http://dx.doi.org/ $10.1353 /$ sof .0 .0243

Coates, Ta-Nehisi Paul. 2007. "Is Obama Black Enough?" Time, February 1.

Crouch, Stanley. 2006. "What Obama Isn't: Black Like Me." New York Daily News, November 2.

Crowley, Michael. 2008. "Post-Racial: Even White Supremacists Don't Hate Obama." New Republic, March 12, pp. 7-8.

Harris, David R. and Jeremiah Joseph Sim. 2002. "Who Is Multiracial? Assessing the Complexity." American Sociological Review 67:614-627. http://dx.doi.org/10.2307/3088948

Herring, Cedric, Verna Keith, and Hayward Derrick Horton, eds. 2004. Skin Deep: How Race and Complexion Matter in the "Color-blind" Era. Chicago: University of Illinois Press.

Kinder, Donald R. and Corrine M. McConnaughy. 2006. "Military Triumph, Racial Transcendence, and Colin Powell." Public Opinion Quarterly 70:139-65. http://dx.doi.org/ $10.1093 / \mathrm{poq} / \mathrm{nfj} 018$

Lanning, Kevin and Geoffrey Maruyama. 2010. "The Social Psychology of the 2008 U.S. Presidential Election." Analyses of Social Issues and Public Policy 10:171-81.http://dx.doi org $/ 10.1111 / j .1530-2415.2010 .01215 . x$

Lee, Jennifer and Frank D. Bean. 2010. The Diversity Paradox: Immigration and the Color Line in 21st Century America. New York: Russell Sage Foundation Press.

Lofquist, Daphne, Terry Lugaila, Martin O'Connell, and Sarah Feliz. 2012. "Households and Families: 2010." U.S. Census Bureau, Washington, DC. 
Moran, Rachel. 2001. Interracial Intimacies: The Regulation of Race and Romance. Chicago: University of Chicago Press.

Morning, Ann. 2005. "Multiracial Classification on the U. S. Census: Myth, Reality, and Future Impact." Revue Européene des Migrations Internationales 21:111-34. http: //dx.doi.org/10.4000/remi.2495

Nossiter, Adam. 2008. "For Some, Uncertainty Starts at Racial Identity." The New York Times, October 14, 2008: p.A21. http://www .nytimes.com/2008/10/ 15/us/politics/15biracial.html?r=0.

Patterson, Orlando. 1997. The Ordeal of Integration. Washington, DC: Civitas/Counterpoint.

Smith, Rogers M. and Desmond S. King. 2009. "Barack Obama and the Future of American Racial Politics." Du Bois Review: Social Science Research on Race 6:25-35. http://dx doi.org/10.1017/S1742058X09090158

Tajfel, Henri. 1981. Human Groups and Social Categories: Studies in Social Psychology. Cambridge: Cambridge University Press.

Acknowledgements: We thank Brian Powell and Melissa Herman for their useful comments.

Simon Cheng: Department of Sociology, University of Connecticut. E-mail: simon.cheng@uconn.edu.

David L. Weakliem: Department of Sociology, University of Connecticut. E-mail: david.weakliem@uconn.edu. 